\title{
Molecules Acting on CB1 Receptor and their Effects on Morphine Withdrawal In Vitro
}

\author{
Anna Capasso* and Chiara Gallo
}

Department of Pharmaceutical Sciences, University of Salerno, Via Ponte Don Melillo (84084) Fisciano, Salerno, Italy

\begin{abstract}
Several pharmacological studies indicate that CB1 cannabinoid receptors (CB1Rs) are present in guinea pig ileum (GPI) and their activation reduce the acetylcholine (Ach) release. Dependence can be induced and measured in vitro by using GPI and the contraction due to opioid withdrawal is caused by acetylcholine release.

Design of molecules acting on the CB1Rs are widely studied and the large availaibility of CB1Rs agonists and antagonists provides powerful tools to determine the role of these receptors in mediating some of physiological and pharmacological effects in the myenteric neurones.

Given the relationship between CB1Rs/Opioid Withdrawal/Ach system, in the present paper we have designed six new CB1Rs agonists named A-F and evaluated their role in mediating morphine withdrawal in GPI. Also, a comparative study was performed by using the CB1Rs synthetic cannabinoid WIN 55,212-2 and CP 55,940. The results of our experiments indicate that both WIN 55,212-2 and CP 55,940 (1 $\left.\times 10^{-8}-5 \times 10^{-8}-1 \times 10^{-7} \mathrm{M}\right)$ were able to reduce morphine withdrawal in a concentration-dependent manner. Very similar results were obtained with the new CB1Rs agonists (A-F) used at same concentrations. The results of our experiments indicate that CB1Rs are involved in the control of morphine withdrawal in vitro thus confirming an important functional interaction between the cannabinoid and opioid system.
\end{abstract}

Keywords: Ach. CB1 receptors, morphine, withdrawal, guinea-pig ileum.

\section{INTRODUCTION}

Cannabinoid drugs exert a wide range of biological effects and are currently under study for their multiple potential therapeutic uses [1-4].

Cannabinoids and opioid share several pharmacological properties [5-7] and a strong interaction between opioid and cannabinoid systems has been reported [8-12]. This interaction can be studied by using GPI where cannabinoid CB1Rs have been found [13, 14]. The enteric nervous system has been considered as a simplified version of the central nervous system, considering its complex networklike organization and the presence of a large number of neurotrasmitters and neuromodulators. Isolated preparations, GPI, have been widely employed for assessing the acute effects of opioid and as a model for studying the interactions of opioid with other neuronal systems.

Dependence can be induced and measured in vitro by using GPI [15-18]. Tissues from untreated animals, after a brief exposure to opioids, show a strong naloxone-induced contracture [15-18] indicating that the cellular mechanisms of dependence may occur very rapidly following occupation of receptors and that these mechanisms operate within the myenteric plexus.

The characteristics of dependence development and the precipitation of withdrawal by naloxone in the guinea-pig

\footnotetext{
*Address correspondence to this author at the Dipartimento di Scienze Farmaceutiche, Università di Salerno, Via Ponte Don Melillo, (84084) Fisciano, Salerno, Italia; Tel/Fax: 0039-089-969744;

E-mail: annacap@unisa.it
}

ileum are very similar to those of acute dependence in experimental animals and man [15-18].

It has been demonstrated that Ach plays an important role in expression of opioid withdrawal because cholinergic agonist exacerbate opioid withdrawal; whereas, muscarinic and nicotinic blockers attenuate some aspects of the syndrome $[19,20]$. Furthermore, a large proportion of the contraction due to opioid withdrawal is caused by acetylcholine release since it can be blocked by atropine or hyoscine [21, 22].

Several pharmacological evidences suggest that CB1Rs are present in the GPI and the effects on gastrointestinal motility depend on their activation which cause a reduction of Ach release [23-27].

Design of molecules acting on the CB1Rs are widely studied and the large availaibility of CB1Rs agonists and antagonists $[28,29]$ provides powerful tools to determine the role of these receptors in mediating some of physiological and pharmacological effects in the myenteric neurones .

Given the relationship between CB1Rs/Opioid Withdrawal/Ach system, in the present paper we have designed new CB1Rs agonists named A-F $[30,31]$ and evaluated their role in mediating morphine withdrawal in GPI. Also, a comparative study was performed by using the CB1Rs synthetic cannabinoid WIN 55,212-2 and CP 55,940.

\section{MATERIALS AND METHODS}

\section{Morphine Withdrawal on Guinea-Pig Ileum}

Male Charles River guinea-pigs (180-200 g) were used for all the experiments. Animal Care and use followed the 
directions of the Council of the European Communities (1986). The animals were housed in colony cage (4 guineapig each) under conditions of standard light (light on from 7.00 a.m. to 7.00 p.m.), temperature $\left(22 \pm 1^{\circ} \mathrm{C}\right)$ and room humidity $(60 \% \pm 10 \%)$ conditions for at least 1 week before the experimental sessions. Food and water were available ad libitum.

The experimental procedure was that described previously [32]. The ilea were allowed to equilibrate for 4060 min without washing and the response to acetylcholine (Ach) was determined for three times $\left(10^{-6} \mathrm{M}\right)$ so that response could be expressed as percentage of Ach maximum. A reproducible acute opiate dependence was obtained performing the following experimental procedure. A typical tracing of contracture responses of the ileum to repeated challenges with opiate and naloxone is shown in Fig. (1).

After three similar Ach responses, the preparation was electrically stimulated for $10-20 \mathrm{~min}$, (0.5 msec pulse delivered transmurally, at a frequency of $10 \mathrm{sec}$ at supramaximal voltage, $25 \mathrm{~V}$ ). Before the addition of the morphine to the bath, the electrical stimulation was switched off. Under these conditions, the first contact with the opioid agonist followed after a 4 min exposure by naloxone induced a strong contraction (about $80 \%$ of the Ach maximum).

However, after washout, another Ach response was performed (to verify whether the ileum responsiveness was modified after withdrawal contracture) (Fig. 1A) and, after $30 \mathrm{~min}$ resting period under stimulation, a further $4 \mathrm{~min}$ exposure of the ileum (without electrical stimulation) to the opiate and naloxone elicited reproducible response.

Following washout, Ach response (Fig. 1B) and another 30 min resting period under stimulation, the ileum responded again to the morphine and naloxone with the same intensity (Fig. 1C). In our experiments, to avoid a possible tolerance for repeated morphine injection, each preparation was submitted only to three challenges with morphine and naloxone. Naloxone per se did not produce effects on "naive" preparations or those washed after opiate contact.

\section{Experimental Procedure}

The administration of CB1Rs agonists WIN 55,212-2, CP 55,940 and A-F was performed according to the following schedule:
a) three Ach response
b) electrical stimulation (10-20 $\mathrm{min})$
c) morphine injection $\left(10^{-5} \mathrm{M}\right)$ in absence of electrical stimulation (4 min) and the addition of naloxone $\left(10^{-5} \mathrm{M}\right)$ with subsequent contraction $\left(1^{\circ}\right.$ opioid withdrawal)
d) washout and Ach response
e) electrical stimulation (30 $\mathrm{min})$
f) CB1Rs agonists WIN 55,212-2, CP 55,940 or A-F $\left(\begin{array}{ll}1 \times 10^{-8}-5 \times 10^{-8}-1 \times 10^{-7} & \mathrm{M}) \text { without electrical }\end{array}\right.$ stimulation injected 10 min before morphine followed by naloxone $\left(2^{\circ}\right.$ opioid withdrawal)
g) washout Ach response

h) electrical stimulation (30 $\mathrm{min})$

i) final control opiate withdrawal ( $3^{\circ}$ opioid withdrawal)

\section{Drugs}

Naloxone $\mathrm{HCl}$ and WIN 55,212-2 $(\mathrm{R}(+)$-(2,3-dihydro5methyl-3-((morpholinyl)methyl)pirrolo-(1.2.3.-sw)-1.4benzoxazinyl)-(1-naphthalenyl)methanone)mesylate, GDP and GTP $\gamma S$ were purchased from Sigma Chemical Co. (St. Louis, MO, USA); morphine $\mathrm{HCl}$ was from Carlo Erba (Milan, Italy), CP 55,940 was obtained from Tocris (Bristol, UK). Rat brains were purchased from Pelfreeze Rogers, AR. $\left[{ }^{35} \mathrm{~S}\right] \mathrm{GTP} \gamma \mathrm{S}$ was purchased from New England Nuclear Corp., Boston, MA.

\section{Parameter Evaluation}

Four parameters were evaluated:

1) Naloxone contracture: the size of the contraction produced by the naloxone challenge was expressed as a fraction of the maximum contraction obtained with the subsequent addition of Ach in the same piece of tissue according to the method previously described [32]:

$$
\frac{\text { Response to naloxone } \mathrm{x} 100}{\text { Maximum response to Ach }}=\text { Tension ratio }
$$

2) Ach response before and after the treatment: reduction or increase of the Ach responses in the post-drug expressed as a percentage of Ach response in the pre-drug.

3) Electrically stimulation contraction before and after the treatment: reduction or increase of the electrically stimulation contraction in the post-drug was expressed as a percentage of the electrical stimulation in the pre-drug.

4) Naloxone contraction before and after treatment: reduction or increase of the naloxone contraction in the post-drug was expressed as a percentage of the naloxone contraction in the pre-drug.

\section{Statistical Analysis}

Results were tested for statistical significance using the Student's $t$-test for paired data when results before and after treatments on the same preparation were compared. The ED50 were computed from the dose-response curve by the method of Litchfield and Wilcoxon [33].

\section{Chemistry Pathway}

The CB1Rs (A-F) were synthesized as described previously [30,31]. Table 1 shows the structures of the new CB1Rs agonists (A-F).

\section{Binding Assay}

\section{1. ${ }^{35}$ S]GTP $\gamma S$ Binding Assay. Cerebellar Membrane Preparation}

The procedure was adapted from the method of Dodd et al. [34] The stripped rat brains were slightly thawed, and using a spatula, the cerebellum was removed and discarded; the remaining tissue was homogenized in ice-cold homogenization buffer $(0.32 \mathrm{M}$ sucrose, $10 \mathrm{mM}$ Tris, $5 \mathrm{mM}$ 

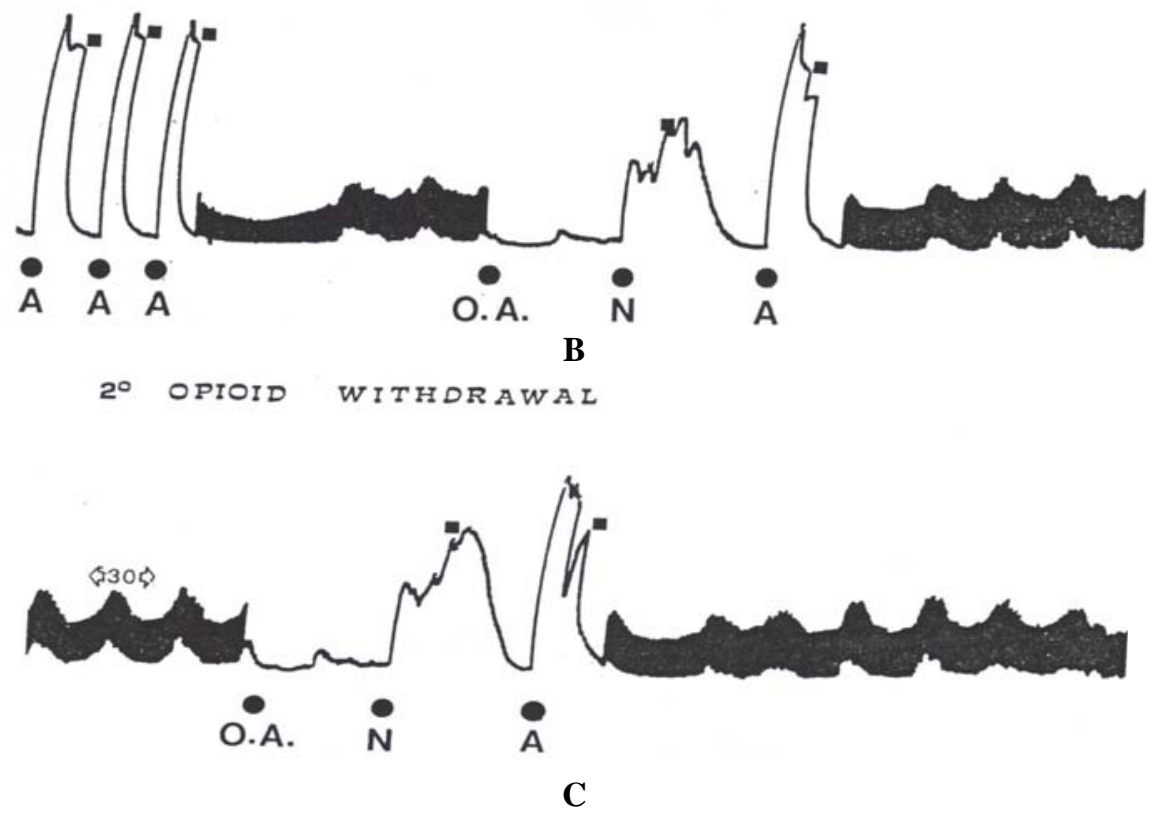

$3^{\circ}$ OPIOID WITHDRAWAL

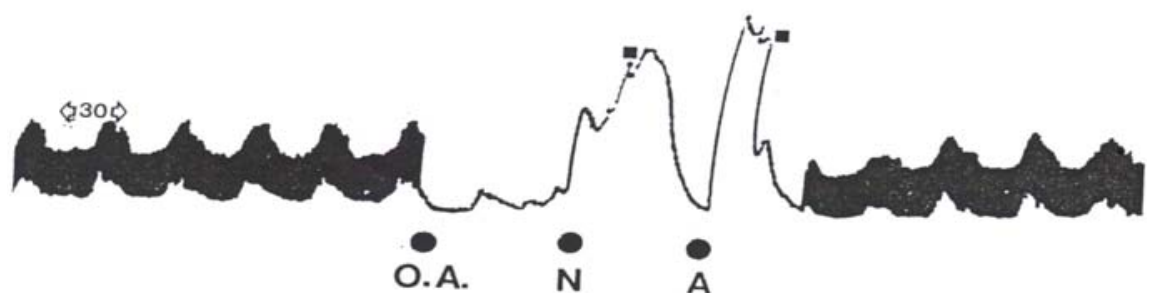

Fig. (1). Typical tracing of opioid withdrawal on guinea-pig ileum. A. 3 similar acetylcholine response (A), electrical stimulation, injection of the opioid agonist (OA) followed after 4 min of contact period by naloxone $(\mathrm{N})$ which induces contraction $\left(1^{\circ}\right.$ opioid withdrawal). After washout $($ ), it was performed another A response.

B: After 30 min resting period under electrical stimulation, a further 4 min exposure of the ileum to the OA and $\mathrm{N}$ elicited reproducible response ( $2^{\circ}$ opioid withdrawal).

C: After another 30 min resting period under electrical stimulation, the ileum responded again to the OA and $\mathrm{N}$ with the same intensity $\left(3^{\circ}\right.$ opioid withdrawal).

\section{Table 1.}

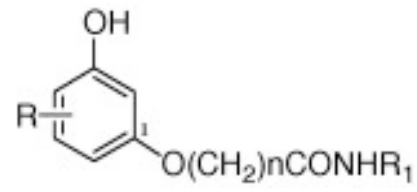

\begin{tabular}{|c|c|c|c|}
\hline CB1 Analogues & $\mathbf{R}$ & $\mathbf{n}$ & $\mathbf{R}_{1}$ \\
\hline CB1R-B & 5-n-phenyl & 5 & c. $\mathrm{C}_{3} \mathrm{H}_{5}$ \\
\hline CB1R-C & 5-n-phenyl & 10 & $\mathrm{CH}_{2}-c-\mathrm{C}_{3} \mathrm{H}_{5}$ \\
\hline CB1R-D & 5-n-phenyl & 10 & $\mathrm{CH}_{2} \mathrm{CH}_{2} \mathrm{OH}$ \\
\hline
\end{tabular}


<smiles>CCCCCCC(C)(C)c1ccc(C2C[C@H](O)CC[C@H]2CCCO)c(O)c1</smiles>

CP-55,940

EDTA, pH 7.4). The homogenate suspension was centrifuged at $3700 \mathrm{~g}$ for $10 \mathrm{~min}$. The supernatant was decanted, and $12 \mathrm{~mL}$ was layered over $10 \mathrm{~mL}$ of $1.2 \mathrm{M}$ sucrose. These tubes were centrifuged in a L7-65 ultracentrifuge using a $50.2 \mathrm{Ti}$ rotor at $4{ }^{\circ} \mathrm{C}$ for $29 \mathrm{~min}$ at 44 $000 \mathrm{rpm}$. The layer at the interface was then removed and subjected to a second sucrose spin over $0.8 \mathrm{M}$ sucrose. The pellet was resuspended in TME buffer $(25 \mathrm{mM}$ Tris base, 5 $\mathrm{mM} \mathrm{MgCl} 2,1 \mathrm{mM}$ EDTA, pH 7.4), aliquoted, and stored at $70{ }^{\circ} \mathrm{C}$. Protein was determined using the method of Markwell et al. [35].

\section{2. [ ${ }^{35}$ SJGTP $\gamma S$ Binding Assay (Table 2)}

Our assay was based on a method by Selley et al. [36] and was adjusted for a 96-well plate analysis. Briefly, the rat membrane preparation $(40-50 \mu \mathrm{g}$ of protein) was incubated for $1 \mathrm{~h}$ at $30{ }^{\circ} \mathrm{C}$ in assay buffer $(10 \mathrm{mM}$ Tris, $100 \mathrm{mM} \mathrm{NaCl}$, $5 \mathrm{mM} \mathrm{MgCl} 2,0.1 \%$ BSA) with $50 \mu \mathrm{L}$ of $50 \mu \mathrm{M}$ GDP, $50 \mu \mathrm{L}$ of $0.05 \mathrm{nM}\left[{ }^{35} \mathrm{~S}\right] \mathrm{GTP} \gamma \mathrm{S}$, or $100 \mu \mathrm{L}$ of either; $10 \mu \mathrm{M}$ GTP $\gamma \mathrm{S}$ was used to measure the nonspecific binding, a series of different concentrations of the analogues being tested, or buffer alone as a control to obtain the baseline of GTP $\gamma \mathrm{S}$ stimulation. The reaction was terminated by rapid filtration through Whatman GF/B filters, with ice-cold wash buffer containing $0.5 \%$ bovine serum albumin using the Packard Filtermate. Bound radioactivity was measured on the Packard Top-Count microplate scintillation counter.

Table 2. $\quad \mathrm{EC}_{50}$ and $E_{\max }$ Values of Anandamide Analogues for Stimulating $\left[{ }^{35}\right.$ S GTP $\gamma$ S Binding in Rat Microsomal Membranes $^{a}$

\begin{tabular}{|c|c|c|}
\hline CB1 Analogues & $\mathbf{E C}_{\mathbf{5 0}}(\boldsymbol{\mu M})$ & $\boldsymbol{E}_{\max }(\boldsymbol{\%})$ \\
\hline \hline A & $0.48 \pm 0.03$ & $112 \pm 4.8$ \\
\hline B & $0.22 \pm 0.07$ & $121 \pm 1.5$ \\
\hline C & $0.34 \pm 0.08$ & $133 \pm 3.5$ \\
\hline D & $0.52 \pm 0.05$ & $108 \pm 2.7$ \\
\hline E & $0.42 \pm 0.03$ & $103 \pm 1.9$ \\
\hline F & $0.27 \pm 0.04$ & $127 \pm 4.5$ \\
\hline WIN 55,212-2 & $0.18 \pm 0.09$ & $144 \pm 6.5$ \\
\hline CP-55,940 & $0.10 \pm 0.05$ & $135 \pm 9.0$ \\
\hline
\end{tabular}

${ }^{a}\left[{ }^{35} \mathrm{~S}\right] \mathrm{GTP} \gamma-\mathrm{S}$ binding assay was conducted using eight concentrations of each analogue being tested and two experiments run with four duplicates of each point.

\section{RESULTS}

Effect of WIN 55,212-2, CP 55,940 or CB1R Agonists (AF) on Morphine Withdrawal

Both WIN 55,212-2 and CP 55,940 (CB1Rs synthetic cannabinoid) at $1 \times 10^{-8}-5 \times 10^{-8}-1 \times 10^{-7} \mathrm{M}$ were able to

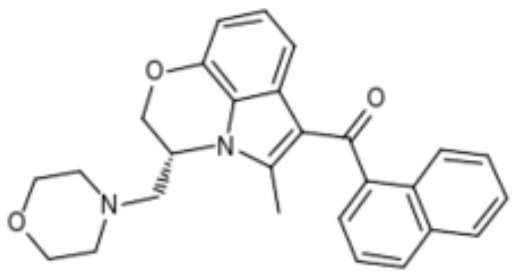

WIN 55,212-2

respectively prevent or reverse the naloxone-induced contraction in GPI exposed to morphine (Table $\mathbf{3}$ ).

Also, six new CB1Rs agonists (A-F) $\left(1 \times 10^{-8}-5 \times 10^{-8}\right.$. $1 \times 10^{-7} \mathrm{M}$ ) were able to reduce morphine withdrawal (Table 3).

Table 3. ED50 and 95\% C.L. Values of CB1Rs Agonist WIN $55,212-2$, CP 55,940 or A-F $\left(1 \times 10^{-8}-5 \times 10^{-8}-1 \times 10^{-7} \mathrm{M}\right)$ on Morphine Withdrawal. Each CB1Rs Agonist was Administered 10 min Before (A) or After (B) Morphine

\begin{tabular}{|c|c|c|}
\hline Compounds & $\begin{array}{c}\text { Morphine Withdrawal } \\
\text { (A) }\end{array}$ & $\begin{array}{c}\text { Morphine Withdrawal } \\
(\text { B })\end{array}$ \\
\hline \hline WIN 55,212-2 & $\begin{array}{c}2.1 \times 10^{-8} \mathrm{M} \\
\left(1.5 \times 10^{-9}-2.4 \times 10^{-7}\right)\end{array}$ & $\begin{array}{c}3.1 \times 10^{-8} \mathrm{M} \\
\left(5.5 \times 10^{-9}-3.1 \times 10^{-7}\right) .\end{array}$ \\
\hline CP 55,940 & $2,5 \times 10^{-8} \mathrm{M}$ & $3.5 \times 10^{-8} \mathrm{M}$ \\
& $\left(3.5 \times 10^{-9}-4.3 \times 10^{-7}\right)$ & $\left(2.7 \times 10^{-9}-4.3 \times 10^{-7}\right)$. \\
\hline CB1R-A & $3.5 \times 10^{-8} \mathrm{M}$ & $3.7 \times 10^{-8} \mathrm{M}$ \\
& $\left(2.5 \times 10^{-9}-1.9 \times 10^{-8}\right)$ & $\left(4.5 \times 10^{-9}-2.3 \times 10^{-7}\right)$ \\
\hline CB1R-B & $2.7 \times 10^{-8} \mathrm{M}$ & $2.9 \times 10^{-8} \mathrm{M}$ \\
& $\left(3.4 \times 10^{-9}-1.7 \times 10^{-8}\right)$ & $\left(3.5 \times 10^{-9}-1.7 \times 10^{-7}\right)$ \\
\hline CB1R-C & $3.1 \times 10^{-8} \mathrm{M}$ & $3.5 \times 10^{-8} \mathrm{M}$ \\
& $\left(2.9 \times 10^{-9}-4.1 \times 10^{-8}\right)$ & $\left(2.5 \times 10^{-9}-4.3 \times 10^{-7}\right)$ \\
\hline CB1R-D & $2.9 \times 10^{-8} \mathrm{M}$ & $2.2 \times 10^{-8} \mathrm{M}$ \\
& $\left(1.3 \times 10^{-9}-3.3 \times 10^{-8}\right)$ & $\left(1.5 \times 10^{-9}-3.3 \times 10^{-7}\right)$ \\
\hline CB1R-E & $2.4 \times 10^{-8} \mathrm{M}$ & $3.2 \times 10^{-8} \mathrm{M}$ \\
& $\left(3.3 \times 10^{-9}-1.9 \times 10^{-8}\right)$ & $\left(4.5 \times 10^{-9}-2.3 \times 10^{-7}\right)$ \\
\hline CB1R-F & $2.5 \times 10^{-8} \mathrm{M}$ & $3.6 \times 10^{-8} \mathrm{M}$ \\
& $\left(3.3 \times 10^{-9}-1.6 \times 10^{-8}\right)$ & $\left(4.5 \times 10^{-9}-2.3 \times 10^{-7}\right)$ \\
\hline
\end{tabular}

Electrical stimulation was also reduced by the above CB1 receptor agonists (Table 4 ), the final morphine withdrawal was still reduced (Table 4), whereas the Ach response was not modified (Data not shown).

\section{DISCUSSION}

While there are several data in literature on the effects exerted by cannabinoids on several effects induced by opioids [37-40], this is the first paper which evaluates the role of CB1Rs agonists in mediating morphine withdrawal in vitro. Furthermore, a comparative study was also performed by using both the well known CB1Rs agonists WIN 55,2122 and CP 55,940 (CB1 synthetic cannabinoid) and six new 
Table 4. The Effect of CB1Rs Agonist WIN 55,212-2, CP 55,940 or A-F $\left[(1) 1 \times 10^{-7}-(2) 5 \times 10^{-8}-(3) 1 \times 10^{-8} \mathrm{M}\right]$ on Electrical Stimulation and Final Opioid Withdrawal

\begin{tabular}{|c|c|c|}
\hline Compounds & $\begin{array}{c}\text { Electrical } \\
\text { Stimulation }\end{array}$ & $\begin{array}{c}\text { Final Morphine } \\
\text { Withdrawal }\end{array}$ \\
\hline WIN 55,212-2 & $\begin{array}{l}75.6 \pm 3.9^{* *} 1 \\
46.8 \pm 2.7^{* *} 2 \\
35.4 \pm 1.6^{* *} 3\end{array}$ & $\begin{array}{c}62.5 \pm 5.3 * * 1 \\
39.7 \pm 3.1 * 2 \\
22.4 \pm 2.33\end{array}$ \\
\hline CP 55,940 & $\begin{array}{c}82.3 \pm 4.8 * * 1 \\
56.3 \pm 2.4 * * 2 \\
37.3 \pm 2.73\end{array}$ & $\begin{array}{c}57.3 \pm 2.5 * * 1 \\
44.8 \pm 4.9 * 2 \\
35.3 \pm 2.43\end{array}$ \\
\hline CB1R-A & $\begin{array}{c}72.8 \pm 2.5 * * 1 \\
49.7 \pm 2.9 * * 2 \\
33.2 \pm 3.63\end{array}$ & $\begin{array}{l}72.3 \pm 3.7 * * 1 \\
57.2 \pm 3.6 * * 2 \\
41.5 \pm 3.2 * 3\end{array}$ \\
\hline CB1R-B & $\begin{array}{c}77.5 \pm 4.2^{* *} 1 \\
59.3 \pm 3.6^{* *} 2 \\
23.7 \pm 2.53\end{array}$ & $\begin{array}{c}69.5 \pm 4.6 * * 1 \\
42.5 \pm 2.3 * * 2 \\
28.7 \pm 3.93\end{array}$ \\
\hline CB1R-C & $\begin{array}{c}69.3 \pm 5.8^{* *} 1 \\
48.4 \pm 3.2 * * 2 \\
32.3 \pm 2.13\end{array}$ & $\begin{array}{l}68.7 \pm 5.1 * * 1 \\
44.3 \pm 2.1 * * 2 \\
20.7 .6 \pm 1.93\end{array}$ \\
\hline CB1R-D & $\begin{array}{c}73.1 \pm 6.7 * * 1 \\
55.1 \pm 3.2 * * 2 \\
38.3 \pm 2.53\end{array}$ & $\begin{array}{c}70.2 \pm 6.2 * * 1 \\
48.2 \pm 3.3 * * 2 \\
27.3 \pm 3.13\end{array}$ \\
\hline CB1R-E & $\begin{array}{c}67.3 \pm 6.1 * * 1 \\
46.9 \pm 2.9 * * 2 \\
36.2 \pm 6.53\end{array}$ & $\begin{array}{c}73.4 \pm 4.3 * * 1 \\
62.5 \pm 2.5 * * 2 \\
44.3 \pm 5.83\end{array}$ \\
\hline CB1R-F & $\begin{array}{l}80.1 \pm 5.7 * * 1 \\
63.9 \pm 3.5 * * 2 \\
49.2 \pm 3.9^{* *} 3\end{array}$ & $\begin{array}{l}79.2 \pm 6.1 * * 1 \\
59.3 \pm 3.1 * * 2 \\
46.2 \pm 2.2 * * 3\end{array}$ \\
\hline
\end{tabular}

Results are expressed as $\%$ of inhibition (mean+s.e.m.); ${ }^{*} \mathrm{P}<0.05 ; * * \mathrm{P}<0.01$. All data were compared to the pre-drug.

CB1Rs agonists (A-F). The results of the present study indicate that both the synthetic cannabinoid WIN 55,212-2 or CP 55,940 as well as the six new CB1Rs agonists (A-F) were able to produce significant reduction on morphine withdrawal in vitro thus confirming the important functional interaction between the cannabinoid and opioid system.

However it is of interest to note that CB1Rs agonists (AF) compared to the synthetic cannabinoid WIN 55,212-2 and CP 55,940 showed a very similar activity in inhibiting morphine withdrawal confirming that CB1Rs agonists (A-F) show a CB1 receptor affinity very similar to WIN 55,212-2 and CP 55,940 as shown in Table 2.

The discussion on the possible mechanism by which CB1Rs agonists causes a reducing effect on morphine withdrawal is open and several possibilities may be considered.

Ach system has been widely implicated in many of the pharmacological effects of opioids. Manipulation that alter the activity of Ach in the central nervous system frequently modify the effects of morphine and other opioid drugs [4144].

Several authors have demonstrated that Ach agonists and antagonists are able to influence opiate withdrawal in vitro, suggesting an important functional interaction between the Ach system and opioid withdrawal [19-22]. Cholinergic agonist exacerbate opioid withdrawal; whereas, muscarinic and nicotinic blockers attenuate some aspects of the syndrome [19-22]. Furthermore, a large proportion of the contraction due to opioid withdrawal is caused by Ach release since it can be blocked by atropine or hyoscine [1922]. Also, it has been demonstrated that also selective muscarinic receptors antagonists are able to influence opioid withdrawal in vitro [45].

Several pharmacological evidences suggest that CB1Rs are present in the myenteric neurones and the effects on gastrointestinal motility depend on the activation of CB1Rs which induce a reduction of Ach release [23-27]. Therefore, the ability of CB1Rs agonists to reduce morphine withdrawal may be related to their ability to block the release of Ach at presynaptic level [23-27] and confirming the role played by Ach in the expression of opiate withdrawal [19-22].

Furthermore, in our experimental conditions, the ability of CB1Rs agonists to reduce electrical stimulation after washout without altering the Ach response at postsynaptic level confirm a direct action on presynaptic Ach receptors [23-27].

Therefore, our data confirm and extend previous data [19-22] indicating a significative role of the cannabinoid system in the development of morphine withdrawal indicating that CB1Rs play an important role in the control of morphine withdrawal probably through Ach system [23, $27,46]$.

However, another possibility should be considered.

The effects of CB1Rs on morphine withdrawal may be also related to their ability to block the release of adrenaline or dopamine by pre-synaptic receptors. Recently, it has been demonstrated that catecolaminergic system is involved in the control of the expression of opioid acute dependence in GPI $[32,47]$. Several studies indicate that CB1Rs are able to block the release of dopamine and noradrenaline at presynaptic level of guinea pig ileum electrically stimulated [48]. Therefore, we cannot exclude the possibility that CB1Rs reduce morphine withdrawal also by blocking the release of catecolamines by the presynaptic neurons.

Regarding the comparative study performed between the well known CB1Rs WIN 55,212-2 and CP 55,940 (CB1 synthetic cannabinoid) and the six new CB1Rs agonists (AF). our data show a good correlation between the binding activity and biological activity,. Therefore, our results indicate that the aromatic structure, the length of aliphatic chain and the chain of 5-10 carbon atoms assure the affinity of compounds to CB1Rs.

Finally, the possible implications of this finding in the context of novel therapeutic aspect may be considered suggesting that CB1Rs activation or inhibition may result benefical as additional therapeutic strategy during opioid withdrawal. 


\section{REFERENCES}

[1] Lynn, A.B.; Herkenham, M. Localization of cannabinoid receptors and nonsaturable high-density cannabinoid binding sites in peripheral tissues of the rat: implications for receptor-mediated immune modulation by cannabinoids. J. Pharmacol. Exp. Ther., 1994, 268, 1612-23.

[2] Massa, F.; Marsicano, G.; Hermann, H.; Cannich, A.; Monory, K.; Cravatt, B.F.; Ferri, G.L.; Sibaev, A.; Storr, M.; Lutz, B. The endogenous cannabinoid system protects against colonic inflammation. J. Clin. Invest., 2004, 113, 1202-9.

[3] Martin, B.R.; Wiley, J.L. Mechanism of action of cannabinoids: how it may lead to treatment of cachexia, emesis, and pain. $J$. Support. Oncol., 2004, 2, 305-16

[4] Pazos, M.R.; Núñez, E.; Benito, C.; Tolon, R.M.; Romero, J. Role of the endocannabinoid system in Alzheimer's disease: New perspectives. Life Sci., 2004, 75, 1907-15.

[5] Lichtman, A.H.; Martin, B.R. Spinal and supraspinal mechanisms of cannabinoid-induced antinociception. J. Pharmacol. Exp. Ther., 1991, 258, 517-23.

[6] Anderson, P.F.; Jackson, D.M.; Chesher, G.R.; Malor, R. Tolerance to the effects of delta-9-tetrahydrocannabinol in mice on intestinal motility, temperature and locomotory activity, Psychopharmacology, 1975, 48, 31-36.

[7] Navarro, M.; Carrera, M.R.; Fratta, A.; Valverde, W.; Cossu, O.; Fattore, G.; Chowen, L.; Gómez, J.A.; del Arco, R.; Villanúa, I.; Maldonado, M.A.; Koob, R.G.F.; Rodríguez de Fonseca, F. Functional interaction between opioid and cannabinoid receptors in drug self-administration. J. Neurosci., 2001, 21, 5344-50.

[8] Welch, S.P. Blockade of cannabinoid-induced antinociception by norbinaltorphimine, but no by $N, N$-diallyl-tyrosine-aibphenylalanine-leucine, ICI 174,864 or naloxone in mice. $J$. Pharmacol. Exp. Ther., 1993, 265, 633-40.

[9] Welch, S.P.; Thomas, C.; Patrick, S. Modulation of cannabinoidinduced antinociception after intracerebroventricular versus intrathecal administration in mice: possible mechanisms for interaction with morphine. J. Pharmacol. Exp. Ther., 1995, 272, 310-21.

[10] Ambrosio, E.; Martin, S.; Garcio-Llecumberri, C.; Crespo, J.A. The nuerobiology of cannabinoid dependence: sex difference and potential interactions between cannabinoid and opioid system. Life Sci., 1999, 65, 687-694.

[11] Manzanares, J.; Corchero, J.; Romero, J.; Fernandez-Ruiz, J.J.; Ramos, J.A.; Fuentes JA. Pharmacological and biochemical interactions between opioids and cannabinoids. Trends Pharmacol. Sci., 1999, 20, 287-294.

[12] Piomelli, D.; Giuffrida, A.; Calignano, A. Rodriguez De Fonseca, F. The endocannabinoid system as a target for therapeutic drugs, Trends Pharmacol. Sci., 2000, 21, 218-24.

[13] Pertwee, R.G.; Fernando, S.R.; Nash, J.E.; Coutts, A.A. Further evidence for the presence of cannabinoid CB1 receptors in guineapig small intestine. Br. J. Pharmacol., 1996, 118, 2199-2205.

[14] Basilico, L.; Parolaro, D.; Colleoni, M.; Costa, B.; Giagnoni, G. Cross-tolerance and convergent dependence between morphine and cannabimimetic agent WIN 55,212-2 in the guinea-pig ileum myenteric plexus. Eur. J. Pharmacol., 1999, 376, 265-71.

[15] Kosersky, D.S.; Harris, R.A.; Harris, L.S. Naloxone-precipitated jumping activity in mice following the acute administration of morphine. Eur. J. Pharmacol., 1974, 26, 122-4

[16] Bickel, W.K.; Stitzer, M.L.; Liebson, I.A. Bigelow, G.E. Acute physical dependence in man: effects of naloxone after brief morphine exposure. J. Pharmacol. Exp. Ther., 1988, 244, 126-32.

[17] Eisenberg, RM. Further studies on the acute dependence produced by morphine in opiate naive rats. Life Sci., 1982, 31, 1531-40.

[18] Krystal, J.H.; Redmond, D.E. A preliminary description of acute physical dependence on morphine in the vervet monkey. Pharmacol. Biochem. Behav., 1983, 18, 289-91

[19] Martin W.R.; Eades C.G. Pharmacological studies of spinal cord adrenergic and cholinergic mechanisms and their relation to physical dependence on morphine. Psychopharmacologia, 1967, 11, 195-223.

[20] Bhargava, H.N.; Way, E.L. Acetylcholinesterase inhibition and morphine effects in morphine tolerant and dependent mice. $J$. Pharmacol. Exp. Ther., 1972, 183, 31-40.

[21] Tsou, K.; Louie, G.; Way, E.L. Manifestations of gut opiate withdrawal contracture and its blockade by capsaicin. Eur. J. Pharmacol., 1982, 81, 377-83.
[22] Chal, L.A. Contracture of guinea-pig ileum on withdrawal of methionine5-enkephalin is mediated by substance P. Br. J. Pharmacol., 1983, 80, 741-49.

[23] Coutts, A.A.; Pertwee, R.G. Inhibition by cannabinoid receptor agonists of acetylcholine release from the guinea-pig myenteric plexus. Br. J. Pharmacol., 1997, 121, 1557-66.

[24] Pertwee, R.G. Cannabinoids and the gastrointestinal tract. Gut, 2001, 48, 859-67.

[25] Heinemann, A.; Shahbazian, A.; Holzer, P. Cannabinoid inhibition of guinea-pig intestinal peristalsis via inhibition of excitatory and activation of inhibitory neural pathways. Neuropharmacology, 1999, 38, 1289-97.

[26] López-Redondo, F., Lees, G.M., Pertwee, R.G. Effects of cannabinoid receptor ligands on electrophysiological properties of myenteric neurones of the guinea-pig ileum. Br. J. Pharmacol., 1997, 122, 330-34.

[27] Coutts, A.A.; Irving, A.J.; Mackie, K.; Pertwee, R.G.; AnaviGoffer, S. Localisation of cannabinoid $\mathrm{CB}(1)$ receptor immunoreactivity in the guinea pig and rat myenteric plexus. $J$. Comp. Neurol., 2002, 448, 410-22.

[28] Pertwee, R.G.; Stevenson, L.A.; Elrick, D.B.; Mechoulam, R.; Corbett, A.D. Inhibitory effects of certain enantiomeric cannabinoids in the mouse vas deferens and the myenteric plexus preparation of guinea-pig small intestine. Br. J. Pharmacol., 1992, 105, 980-84.

[29] Pertwee, R.G.; Fernando, S.R.; Griffin, G.; Abadji, V.; Makriyannis, A. Effect of phenylmethylsulphonyl fluoride on the potency of anandamide as an inhibitor of electrically evoked contractions in two isolated tissue preparations. Eur. J. Pharmacol., 1995, 272, 73-78.

[30] Bisogno, T.; Cascio, M.G.; Saha. B.; Mahadevan, A.; Urbani, P.; Minassi, A.; Appendino, G.; Saturnino, C.; Martin, B.; Razdan, R.; Di Marzo, V. Development of the first potent and specific inhibitors of endocannabinoid biosynthesis. Biochem. Biophys. Acta., 2006, 1761, 205-12.

[31] Urbani, P.; Cascio, M.G.; Ramunno, A.; Bisogno, T.; Saturnino, C.; Di Marzo, V. Novel sterically hindered cannabinoid CB1 receptor ligands. Bioorg. Med. Chem., 2008, 16, 7510-5.

[32] Capasso, A.; Sorrentino, L. Differential influence of $D_{1}$ and $D_{2}$ dopamine receptors on acute opiate withdrawal in guinea-pig isolated ileum. Br. J. Pharmacol., 1997, 120, 1001-6.

[33] Tallarida, R.J.; Murray, R.B. Manual of Pharmacologic Calculation with Computer Programs". $2^{\text {nd }}$ ed., Springer Verlag: New York 1987

[34] Dodd, P.R.; Hardy, J.A.; Oakley, A.E.; Edwardson, J.A.; Perry, E.K.; Delaunoy, J.-P. A rapid method for preparing synaptosomes: comparison, with alternative procedures. Brain Res., 1981, 226, 107-118.

[35] Markwell, M.A.K.; Haas, S.M.; Beiber, L.L.; Tolbert, N.E. Modification of the lowry procedure to simplify protein determination in membrane and lipoprotein samples. Anal. Biochem., 1978, 87, 206-210.

[36] Selley, D.E.; Stark, S.; Sim, L.J. Cannabinoid receptor stimulation of guanosine-5'-0-3 $\left[{ }^{35} \mathrm{~S}\right]$ thio)triphosphate binding in rat brain membranes. Life Sci., 1996, 59, 659-668.

[37] Manzanares, J.; Corchero, J. Romero Fernandez-Ruiz, J.J.; Ramos, J.A.; Fuentes, J.A. Trends Pharmacol. Sci., 1999, 20, 112.

[38] Smith, P.B.; Welch, S.P.; Martin, B.R. Interactions between delta 9-tetrahydrocannabinol and kappa opioids in mice. J. Pharmacol. Exp. Ther., 1994, 268, 1381-87.

[39] Vela, G.; Ruiz-Gayo, M; Fuentes, J.A. Anandamide decreases Naloxone-precipitated withdrawal signs in mice chronically treated with morphine, Neuropharmacology, 1995, 34, 665-668

[40] Navarro, M.; Chowen, J.; Rocio, A.; Carrera, M.; del Arco, I.; Villanua, M.A. CB1 cannabinoid receptor antagonist-induced opiate withdrawal in morphine-dependent rats. Neuroreport, 1998 , 9, 3397-3402

[41] Dirksen, R.; Nijhuis, G.M. The relevance of cholinergic transmission at the spinal level to opiate effectiveness. Eur. J. Pharmacol., 1983, 22, 215-221.

[42] Chiang, C.Y.; Zhuo, M. Evidence for the involvement of a descending cholinergic pathway in systemic morphine analgesia. Brain Res., 1989, 30, 293-300.

[43] Lipman, J.J.; Spencer, P.S. A comparison of muscarinic cholinergic involvement in the antinociceptive effects of morphine and clonidine in the mouse. Eur. J. Pharmacol., 1980, 27, 249-58. 
[44] Wong, C.L.; Bentley, G.A. Further studies on the role of cholinergic mechanisms in the development of increased naloxone potency in mice. Eur. J. Pharmacol., 1979, 56, 115-21.

[45] Capasso, A. The Role of Muscarinic Receptors in the Control of Acute Opioid Withdrawal. Lett. Drug Des. Discov., 2007, 4, 207211

[46] Coutts, A.A.; Anavi-Goffer, S.; Ross, R.A.; MacEwan, D.J.; Mackie, K.; Pertwee, R.G. Agonist-induced internalization and trafficking of cannabinoid $\mathrm{CB}_{1}$ receptors in hippocampal neurons. Neuroscience, 2001, 21, 2425-33.
[47] Valeri, P.; Martinelli, B.; Morrone, L.A.; Severini, C. Reproducible withdrawal contractions of isolated ea-pig ileum after brief morphine exposure: effects of clonidine and nifedipine. J. Pharm. Pharmacol., 1990, 42, 115-120.

[48] Schlicker, E.; Kathmann, M. Modulation of transmitter release via presynaptic cannabinoid receptors. Trends Pharmacol. Sci., 2001, $22,565-72$

(C) Capasso and Gallo; Licensee Bentham Open.

This is an open access article licensed under the terms of the Creative Commons Attribution Non-Commercial License (http://creativecommons.org/licenses/by-nc/3.0/) which permits unrestricted, non-commercial use, distribution and reproduction in any medium, provided the work is properly cited. 